\title{
The Internal Senses in Nemesius, Plotinus and Galen: The Beginning of an Idea
}

\author{
Muhammad U. Faruque
}

This study traces the notion of the internal senses in three ancient authors, namely Nemesius, Plotinus and Galen. It begins with Nemesius, and then by going backward ends with Galen. The textual evidence investigated in this study shows clearly that Galen, after acknowledging the Platonic tripartite soul, locates the various dunameis of the soul in the brain. The "localization" theory of Galen plays a crucial role in paving the way for the foundation of the internal senses, which both Plotinus and Nemesius adopted. Just as with the external senses one can locate various sense-organs in different parts of the body, viz., touch, smell, sight etc., so too with the internal senses, one is able to locate them in various parts of the brain. Thus philosophers are able to explain the role of all these different (internal) senses in their account of sense-perception.

\section{Introduction}

The internal senses - as they are so called - were an integral part of both Medieval and Ancient philosophy, especially as they relate to epistemology (perception) and psychology (faculties of the soul). Although the first explicit coinage of the term occurred in St. Augustine, the theory of the internal sense retained its relevance as late as in Kant, for whom the distinction between "inner sense" (innere Sinn) and "apperception" (Apperzeption) is axiomatic in his Kritik der reinen Vernunft (Critique of Pure Reason). ${ }^{1}$ In the present endeavor, however, attempts will

\footnotetext{
${ }^{1}$ Kant makes a crucial distinction between inner sense and the pure apperception (self-consciousness) of the "I think" or cogito. Apperception is the term originally used by Leibniz in his New Essays Concerning Human Understanding (published posthumously in 1765) from the French s'apercevoir de, meaning 'to be aware of.' According to Kant, the perceptions of inner sense have no transcendental reference unlike the transcendental subject of the "I think". The latter is the spontaneous source of synthesis, while the former, as a sense, is passive and receptive. In Kantian epistemology, as presented in the Critique of Pure Reason, all representations are subject to the synthetic unity of apperception. That is to say, the cogito (I think) must be able to accompany all the representations for otherwise something would be represented in the subject which could not be thought of in the first place (CPR B153-4). [Immanuel Kant (1781/1787), Critique of Pure Reason, P. Guyer and A. Wood (trans.), (Cambridge and NY: Cambridge University Press, 1997). References to $C P R$ are in the standard pagination of the $1^{\text {st }}(A)$ and $2^{\text {nd }}(B)$ editions.] See also H. A. Wolfson, "The Internal Senses in Latin, Arabic, and Hebrew Philosophical
} 
be made to trace the foundation of the internal senses in three ancient philosophers, namely Nemesius, Plotinus, and Galen. It will be argued, in the course of our analysis, that although explicit mention of the term may be lacking in the writings of these figures, their discussion of the various faculties (dunameis) of the soul laid the cornerstone of the theory of the internal senses that became important in subsequent philosophical traditions. We will begin with Nemesius of Emesa, a Christian bishop active in the late fourth century AD, who composed an important treatise On the Nature of Man, in which clear traces of the discussion of the internal senses can be discerned. Then, working backward, we will proceed to investigate how Nemesius' formulation might have been influenced and informed by two earlier thinkers, namely Plotinus and Galen. However, before diving into the actual texts of the authors in question, an explanation of the term "internal senses" is in order.

The "internal senses" (La. sensus interiores) are a collection of mental faculties which ancient philosophers located in the brain, and to which they assigned the various functions which were associated with the imagination ${ }^{2}$ (phantasia) and the common sense (koine-aisthesis; Latin sensus communis) throughout Aristotle's De anima and Parva naturalia. In general, the internal senses refer to the post-sensationary faculties that operate without bodily organs. ${ }^{3}$

It would be instructive, at this stage, to delineate the epistemic justification (why distinct faculties are necessary to explain internal perception) of the internal senses, since doing so will clarify its broader context. One of the better formulations of the notion of the internal senses can be found in the works of the great medieval philosopher Avicenna (d. 1037), hence we will briefly touch upon his account of them. Avicenna invokes three epistemological principles in order to deduce the number of internal senses: ${ }^{4}$

Texts," The Harvard Theological Review 28, no. 2 (1935): 128 and Paul Guyer, Kant and the Claims of Knowledge (Cambridge and NY: Cambridge University Press, 1987), $131 \mathrm{ff}$.

${ }^{2}$ Phantasia is rendered imagination, but at times it would be helpful to translate it as "representation."

${ }^{3}$ See, e.g. Wolfson, The Internal Senses, 69. For an alternative definition of the internal senses (based on first-order and second order perceptions), see Thomas K. Johansen, In Defense of Inner Sense: Aristotle on Perceiving that One Sees, Proceedings of the Boston Area Colloquium in Ancient Philosophy 7 (2005): 23.

${ }^{4}$ Avicenna, al-Shifă': Fī al-nafs I.5, 43-45 in Fazlur Rahman (ed.), Avicenna's De anima (Arabic text). Being the Psychological Part of Kitāb al-Shifā' (London: Oxford University Press: 1959). See also Debora L. Black, "Imagination and Estimation: Arabic Paradigms and Western Transformations," Topoi, 19 (2000) 59-75, and 'Estimation (wahm) in Avicenna: The Logical and Psychological Dimensions,' Dialogue 32: 219-258; D. N. Hasse, 'Avicenna on Abstraction,' in R. Wisnovsky (ed.), Aspects of 
1. Each distinct type of sensible object requires a distinct faculty in order to be perceived. The post-sensationary objects of cognition include two such distinct types of objects, the forms of the common sensibles (Ar. suwar al-mahsūusāt) and the "inherent meaning" of those sensibles (Ar. ma' 'āñ al-maḥsūsāt).

2. Since passivity and activity are mutually exclusive, active and passive relations to an object require two respective faculties.

3. Receptive and retentive faculties are distinguished because of different material qualities required in their respective organs. Thus the same faculty cannot both receive and retain a sensible object, which means there must two different faculties.

The application of the above criteria, according to Avicenna, yields a system of five faculties:

1. common sense (Ar. al-hiss al-mushtarak): reception of forms

2. receptive imagination (Ar. khayāl) or the formative faculty: retention of forms

3. estimation (Ar. wahm): reception of meanings

4. memory (dhikr) or the retentive faculty: retention of meanings

5. active imagination (Ar. al-quwwa al-mutakhayyila) or cogitation (Ar. fikr): separation and combination of forms and meanings. ${ }^{5}$

It is to be noted that Avicenna, like his ancient counterparts such as Nemesius, ${ }^{6}$ located the internal senses in different parts of the brain: the common sense and receptive imagination in the front part of the brain; the active imagination and estimation in the middle part, and memory in the rear part of the brain. In what follows, we will analyze the description of the internal senses in the three above-mentioned figures, and attempt to draw a comparative summary.

\section{Nemesius: the Faculties of the Soul and their Bodily Instruments}

The subject matter of Nemesius' treatise On the Nature of Man is the nature of human beings and their place in the larger of scheme of the universe. The treatise encompasses a wide range of topics from the physiological functioning of humans to the question of their providential concern

Avicenna (Princeton: Markus Wiener Publishers, 2001), 39-72; Henrik Lagerlund (ed.), Forming the Mind: Essays on the Internal Senses and the Mind/Body Problem from Avicenna to the Medical Enlightenment (Dordrecht: Springer, 2007); passim.

${ }^{5}$ Avicenna, al-Shifā': fi al-nafs I.5, 44-45. For alternative classifications in Avicenna, see Wolfson, The Internal Senses, 276-82.

${ }^{6}$ For Galen's view on this see section IV of this essay. 
as decreed by God. Nemesius wrote mainly in the Christian context of the fourth century AD, although he often engages in debate with the pagans, in addition to fellow Christians of the era. He makes extensive use of Greek philosophical sources in such a way that his text is not only evidence for the pagan debates but also a contribution to them in its own right. The anatomical/psychological writings of Galen and the standard corpus of Plato, Aristotle, and some Neoplatonists such as Porphyry are all major influence on Nemesius. ${ }^{7}$ He also takes stock of Plotinus' views on the soul. ${ }^{8}$

Nemesius claims that the body is the instrument of the soul, and it is divided in accordance with the faculties (dunameis) of the soul. He enumerates the faculties of the soul as the following: imagination, thought, and memory. And he explains "imagination" in the following:

Imagination (to phantastikon) is a faculty (dunamis) of the non-rational part of the soul that acts through the sense-organs. The imagined is that which is the object of imagination, as the sensed is the object of sensation. An image is an affection of the non-rational soul that comes about through something imagined. An apparition is an empty affection in the non-rational parts of the soul caused by nothing imagined... The organs of imagination are the frontal cavities of the brain, the psychic pneuma within them, the nerves from them soaked with the psychic pneuma and the apparatus of the sense-organs. ${ }^{9}$

For Nemesiuas, as for Galen, the soul is divided into rational and non-rational parts. ${ }^{10}$ Thus the imagination belongs to the non-rational part, and it is a faculty that acts as a function of sense-perception (aisthesis). Like the Stoics, Nemesius states that the whole process of imagination involves four distinct categories:

1. imagination which is an empty attraction without an imagined object

2. imagined (to phantaston) which is the object imagined

3. the image (phantasia) which is the experience, impression or effect caused by the imagined object

4. apparition (phantasma) which is an image not caused by an external object but merely a product of mind ${ }^{11}$

\footnotetext{
${ }^{7}$ Nemesius, On the Nature of Man, trans. R. W. Sharples and P. J. van der Eijk (Liverpool: Liverpool University Press, 1-3.

${ }^{8}$ Ibid., 1, 35.

${ }^{9}$ Ibid., 6, 100-01.

${ }^{10}$ Ibid., 15, $125 \mathrm{ff}$.

${ }^{11}$ Ibid., 6, 100. For the Stoic classification cf. Aëtius/Pseudo-Plutarch, Tenets 4.12 (= SVF 2.54), where this distinction is attributed to Chrysippus. Nemesius presents some verbal resemblances to this chapter, and uses the same tradition (cf. also Pseudo-Galen, Historia philosopha (1914, 4-27).
} 
Although Nemesius does not dedicate a separate section on the common-sense, his description of perception seems to entail the latter. He states that there are five sense-organs but only one sense, that of the soul, which recognizes through the sense-organs the affections that occur in them. As he asserts:

Sensation is not an alteration, but the recognition of an alteration: for the sense-organs are altered and the sense recognizes the alteration; often the sense-organs are called senses, but a sensation is a reception ${ }^{12}$ of objects of sense... There is also this [definition of sensation]: a power of the soul to receive objects of sense, while a sense-organ is an instrument for the reception of objects of sense. ${ }^{13}$

The idea that sensation (or sense-perception) is a receptive activity suggests that there is something (i.e. a faculty) that receives sense data through the sense-organs. He also claims that this "faculty of the soul," together with the sense-organs, receives external data through the imagination. ${ }^{14}$ In addition, Nemesius maintains that some faculties of the soul are subordinate in relation to others. In his view, thought and understanding (to dianoetikon kai to epistemonikon) are commanding faculties, while sense, movement according to impulse, and the imagination are subordinate faculties as they obey the ruling of "reason" without any delay. ${ }^{15}$

After describing the imagination, Nemesius briefly expounds on "thought" as that which constitutes judgement, assent, avoidance, and impulse. He says that its organ is the central cavity of the brain and the psychic pneuma within the cavity. ${ }^{16}$ However, at another place, he identifies thought with reasoning. He then divides reasoning into "immanent" and "expressed reason:"

\footnotetext{
${ }^{12}$ Reception here is translated as antilepsis.

${ }^{13}$ Ibid., 6, 102-03. The view that sensation is a kind of alteration (alloiosis) is considered somewhat vaguely by Aristotle (cf. On the Soul 415b24; 416b34; 417b5ff; On Dreams 459b3-5; On the Parts of Animals 641b6), although he also states that it is not an alteration in the full sense of the word (On the Soul 417b5ff.). The view that sensation is a recognition or discernment (diagnosis) of alteration is found in Galen, On the Doctrines of Hippocrates and Plato 7.6.30-31, De Lacy trans.

${ }^{14}$ Nemesius, On the Nature 6, 103.

15 Ibid.

${ }^{16}$ Ibid., 12, 117. Nemesius distinguishes between to dianoetikon and to epistemonikon, and this perhaps corresponds to dianoesis and noesis (attributed to Plato in the same treatise). Noesis has as its objects 'the proper objects of thought,' which have no basis in sense-perception. The identification of thought with judgement, assent etc. is of Stoic origin. Cf. also Aëtius/Pseudo-Plutarch, Tenets 4.21. See the footnote by Sharples et al.
} 
Immanent (endiathetos) reason is a motion of the soul which occurs in the speech function without any speaking aloud, which is why we often go through a whole reasoning process by ourselves in silence and converse in dreams... Expressed (prophorikos) reason has its activity in speech and in conversation. ${ }^{17}$

The above division, Nemesius states, is another way of dividing the faculties of the soul according to their bodily parts. As it stands, immanent reason refers to the silent discourse that everyone is entitled to have with herself, while expressed reason refers to the more social function of speech. He then goes on to elaborate on the physiology of "speech," largely adapted from Galen's On the Usefulness of the Parts of the Body. After this, Nemesius proceeds to analyze memory (mneme) and its relation to imagination. According to Nemesius, the sensibles are the proper objects of memory, while there is also recollection (anamnesis) of innate ideas:

The faculty of memory is the cause and storehouse of memory and recollection. According to Origen, memory is the imagination left behind by an actually appearing sensation, according to Plato the preservation of sensation and thought. For the soul grasps objects of sense through the sense-organs and an opinion is formed, while it grasps things intelligible through the intellect and intellection comes about: when the soul preserves the imprints of what it has experienced and of what it has conceived it is said to remember. ${ }^{19}$

So the faculty of memory preserves what we have seen, heard, or thought. Nemesius quotes both Origen and Plato to suggest that memory concerns the preservation of sensation. He goes on to maintain that the proper objects of memory are the sensibles, of which opinion can be formed, whereas recollection of the forms is not attained through remembering but through learning and "natural intuition." "20 Toward the end of the chapter, Nemesius explains how information flows from the imagination to reasoning, and then from reasoning to memory. Also, like the faculties of imagination and thought, memory is also assigned a physical location in the brain:

\footnotetext{
${ }^{17}$ Nemesius, On the Nature 14, 123-24.

${ }^{18}$ Galen, On the Usefulness of the Parts of the Body 7.5, 7.11, and 7.20, trans. M. T. May. Galen treats the physiology of speech in detail, but he also refers there for even more extensive treatment to his work On the Voice, which survives only in fragments. See also Galen, On the Affected Parts 1.6 (8.50-53) K and 4.9 (8.266-68 K), trans. Siegel: "the formation of voice (phone) is the function of the sound organs, but the production of speech (dialektos) of the speech organs, the most important of which is the tongue, while nose, lips and teeth support speech considerably... the larynx and the muscles which move it are phonetic organs, and so are the nerves which conduct the power of the brain to these (parts)." On the function of these "nerves" see On the Usefulness of the Parts of the Body 7.17.

${ }^{19}$ Nemesius, On the Nature 13, 119-20.

${ }^{20}$ Ibid., 120. This is so because phantasia is not involved in their cognition.
} 
Thus the faculty of imagination hands on things imagined to the faculty of thought, while thought or reasoning, when it has received and judged them, passes them on to the faculty of memory. The organ of memory, too, is the posterior cavity of the brain, which they call the cerebellum and the enkranis, and the psychic pneuma within it. ${ }^{21}$

\section{Plotinus: there is more to the Soul than its Faculties}

In Plotinus' view, the soul is not in the body; rather the body is in the soul. This way of looking at things, as we shall see when we get to Galen, is diametrically opposed to reducing the soul to its various faculties, some of whose activities, he would admit, are located in the body. ${ }^{22}$ True, Plotinus draws on the anatomical findings presented by Galen in his On the Doctrines of Hippocrates and Plato, but at the same time he appropriates the latter's demonstration in such a way as to safeguard the unity and incorporeality of the soul. ${ }^{23}$ Thus, according to him, the parts of the soul are not "in" the three main bodily organs (i.e. the brain, the heart and the liver) in the ordinary sense-only their "activity" takes place there. ${ }^{24}$ Plotinus avers that the essential functions of the soul consist in contemplating the forms and finding a paradigm of the sensible world in it. ${ }^{25}$ Thus, it is the $\log o s^{26}$ of everything, and its main functions are intellection and perception respectively. It is within this paradigm that we should seek to explain why the Plotinian soul has distinct faculties, with the reasoning faculty securing the top spot. The following passage sheds considerable light on this:

${ }^{21}$ Ibid., 121. The notion of "psychic pneuma was first developed in Hellenistic medicine, especially by Erasistratus and in Stoic psychological theory, and further systematized by Galen which was adopted by Nemesius. Pneuma is believed to flow through the nerves and to mediate sensory and motor signals between the sense-organs and the brian. For more information, see the note in Sharples et al (121). For an extensive discussion of "pneuma," see Julius Rocca, "From doubt to certainty. Aspects of the conceptualisation and interpretation of Galen's natural pneuma," in M. Horstmanshoff, H. King, C. Zittel (eds), Blood, Sweat and Tears. The Changing Concepts of Physiology from Antiquity into Early Modern Europe (Leiden: Brill, 2012), 629-659.

${ }^{22}$ Plotinus, Enneads 4.3.23 and 4.3.24.25-29, trans. Armstrong. See also Eyjolfur K. Emilsson, Plotinus on Sense-Perception: A Philosophical Study (Cambridge: Cambridge University Press: 1988), 34-35.

${ }^{23}$ For an emphasis on this point, see Teun Tieleman, "Plotinus on the seat of the soul: reverberations of Galen and Alexander in Enn. IV, 3 [27], 23," Phronesis 43 (4), 306-325.

${ }^{24}$ Plotinus, Enneads 4.3.23.30-38.

${ }^{25}$ Damian Caluori 2005, "the Essential Functions of a Plotinian Soul," Rhizai 2, no. 1 (2005): 75-94, at 82.

${ }^{26}$ For the meaning of logos, see n. 34. 
When the ensouled body is illumined by soul, one part of it participates in one way and one in another... so the power of eyes is called that of sight, the power in the ears that of hearing... that of touch in the whole body: for the whole body is sense-organ to the soul for this perception. Since the organs of touch are in the first nerves, which also have the power to set the living being in motion because the appropriate soul-power communicates itself at this point, and since these nerves begin in the brain, they established the principle of perception and of impulse and in general of the whole living being in the brain, assuming that obviously that which was going to use the organs would be there where their beginnings were- but it would be better to say that the beginning of the actualization of the potency [of perception] is there... the beginning of its actualization at the point where organ begins. Since, then, the power of sensation which is also that of impulsion, belonging to the soul which perceives and imagines, has reason above it, as it were a nature in close contact on its underside with that which this is above, the ancients thus put reason at the highest point ${ }^{27}$ of the whole living creature at the head, supposing it to be not in the brain but in this perceptive faculty which in the way described above was situated in the brain. ${ }^{28}$

As anatomical researches advanced considerably in the time of Plotinus, the latter made use of these data in order to establish the claim that (the activity) of reason resides in the nerves situated in the brain. He accepts the idea that the nerves are responsible for perception, and since these nerves reside the in brain, the faculty which is going to use them (i.e. the reasoning faculty) would also be there where these nerves are found. In the following passage, Plotinus reworks the theory of the Platonic tripartite soul ${ }^{29}$, and locates the three parts (mere) in three distinct organs of the body:

For the perceptive part of the soul is in some way capable of judgement, and the imaging part has a sort of intelligence, and impulse and desire are there following the lead of the imaging faculty, and reason. The reasoning part therefore is there in the perceptive not as in a place but because that which is there draws upon it... The part of the soul too which we have in common with plants, which is responsible for growth and nutrition, is not absent from any part of the body, and since it nourishes blood by means of the blood, and the nourishing blood is in veins, and the starting point of veins and blood is in the liver,... For that which generates and nourishes and produces growth must necessarily also have an appetite for generation, nourishment and growth. But since the thin, light, quick, pure blood is the proper organ for the spirited part of the soul, the spring of this, the heart---for this is where blood of this kind is separated out... is... dwelling place... of the spirited part. ${ }^{30}$

The "localization" of the faculties played an important role in the development of the theory of the internal senses, which will be discussed in detail in the concluding section of this essay. It may well be the case that it was due to the "localization" of the faculties of the soul that Plotinus came to distinguish various faculties from one another. Because if different faculties of

\footnotetext{
${ }^{27}$ Italics mine.

${ }^{28}$ Plotinus, Enneads 4.3.23.1-15 and 4.3.23.18-28.

${ }^{29}$ Henry J. Blumenthal, Plotinus' Psychology: His Doctrines of the Embodied Soul (Martinus Nihjoff: the Hague, 1971), ch. 3.

${ }^{30}$ Plotinus, Enneads 4.3.23.30-48.
} 
the soul reside in different organs of the body, as has been discovered through scientific research, then their functions too will be different from one another, as can be seen from the above citation. On the other hand, the reason for distinguishing different faculties may be due to the perceptual content of cognition, as it shows variation with respect to the analysis of the object perceived.

It should be noted that for Plotinus, perception is not an impression in the soul, so memory cannot be the preservation of an impression in the soul. ${ }^{31}$ The argument about the function of memory is based on a thesis about the nature of soul, which Plotinus describes as the expression $(\log o s)^{32}$ of ideas and perception. ${ }^{33}$ This thesis allows Plotinus to argue that the soul has objects without having them as impressions or having been affected by them. ${ }^{34}$ That is why, Plotinus argues that the soul has memory of things which it does not have, i.e., it has not 'acquired' them through experience or learning. This theory of memory is based on a notion of soul that is active both in perception and thought. In it, the content of memory possesses sensible and intelligible objects, that is, perceptions and innate ideas which do not have to be acquired by the soul since they are inherent in it. ${ }^{35}$ Plotinus states:

Memory, then, will belong to the image-making power, and remembering will be of things of the mental image kind... ${ }^{36}$ But one must understand memory not only in the sense of a kind of perception that one is remembering, but as existing when the soul is disposed according to what it has previously experienced or contemplated... ${ }^{37}$ So both perception and memory are a kind of strength. Further, when sense-perceptions

31 A large number of studies exists on Plotinus' views on memory, see e.g. Blumenthal, Plotinus' Psychology, 80-89; E. W. Warren, "Memory in Plotinus," CQ 15 (1965): 252-260; Luc Brisson, "La place de la mémoire dans la psychologie plotinienne," Etudes platoniciennes 3 (2006): 13-27; G. M. Hutchinson, "Apprehension of thought in Ennead 4.3.30," The International Journal of the Platonic Tradition 5 (2011): 262-82; R. A. H. King, Aristotle and Plotinus on Memory (Berlin and New York: Walter de Gruyter, 2009); Dimitri Nikulin, "Memory and Recollection in Plotinus," Archiv für Geschichte der Philosophie 96 (2014): 183-201. Among these studies King (2009) provides the most comprehensive study of Plotinus' theory of memory and recollection.

${ }^{32}$ The word logos is always difficult to render given its multifaceted meanings, which vary from context to context. It refers to articulation, and the capacity to express thoughts and feelings in language, either through speech or internally. However, neither "speech" nor "reason" captures it fully, while "discourse" in English seems to have connotations of external activity. Therefore, it is left untranslated most of the time.

${ }^{33}$ Plotinus, Enneads 4.6.3.1.

${ }^{34}$ King, Aristotle and Plotinus on Memory, 111.

${ }^{35}$ Ibid., $114 \mathrm{ff}$.

${ }^{36}$ Plotinus, Enneads 4.3.29.32-35.

${ }^{37}$ Ibid., 4.4.4.8-13. 
are not impressions, how could memories be retentions of imprints which were never made [in the soul] at all? But if memory is a faculty and a preparation for readiness, why do we not come to recall the same things at once, but only later? Because one needs to set up the faculty, so to speak, and get ready. ${ }^{38}$ Thus, because memory is a faculty of and within the soul, memory belongs to the soul only, and not to the composite of the soul and body. ${ }^{39}$

In the above, Plotinus denies that memory belongs to the body because according to him the body is a hindrance to memory and causes forgetfulness. ${ }^{40}$ Moreover, memory is not affection (pathos); it is rather a power/faculty, because, first, an image is an affection ${ }^{41}$ and memory does not operate with images; and second, being affected is opposite of being capable of doing something. ${ }^{42}$ Memory is "strength" $(\text { ischus })^{43}$ that allows the soul to actualize and bring to life what it had once thought or perceived.

In Plotinus' hierarchy of realities (i.e. the One, the Intellect, and the Soul), an object of thinking/intellection (noema), on the one hand, is intellected by the intellect (nous) and is further represented in discursive thinking (dianoia) by the logos as an argument or verbal expression. The nous and the dianoia both know the intelligible, but whereas the former conceives it in a singular act, the latter apprehends it in a logical or verbal arrangement. ${ }^{44}$ The dianoetic object can also be reflected as an imaginary representation (phantasma) in the imagination (phantasia, or image-making power, to phantastikon) capable of such representations. In Plotinus' own words:

Perhaps the reception into the image making power would be of the "logos" which accompanies the act of intelligence. The intellectual act is without parts and has not, so to speak, come out into the open, but remains unobserved within, but the logos unfolds its content and brings it out of the intellectual act into the image-making power, and so shows the intellectual act as if in a mirror, and this is how there is apprehension and persistence and memory of it. Therefore, even though the soul is always moved to intelligent activity, it is when it comes to be in the image-making power that we apprehend it. ${ }^{45}$

\footnotetext{
${ }^{38}$ Ibid., 4.6.3.55-62.

${ }^{39}$ Ibid., 4.3.26.55-57.

${ }^{40}$ Ibid., 4.3.26.50-54.

${ }^{41}$ Ibid., 4.6.3.47ff.

${ }^{42}$ Ibid., 4.6.2.2ff.

${ }^{43}$ Ibid., 4.6.3.55.

${ }^{44}$ Ibid., 4.6.2.7-16.

${ }^{45}$ Ibid., 4.3.30.5-14.
} 
According to Plotinus, we become aware of our sensation and desires by apprehending the images that are formed in the faculty of the imagination (phantasia). ${ }^{46}$ Thus the object of apprehension presents itself as an image. As for the higher cognition of the soul, we become conscious of our thoughts once logoi have unfolded their content and displayed them in the imagination like a mirror. Here the intentional object is a logos. What is important to note is that discursive reasoning unfolded by logoi are the external acts of the Forms in the Intellect. And insofar as they are the external acts of the Forms, they are images or traces. Hence, the logoi that unfold thoughts into the imagination are image-like. Plotinus uses the mirror metaphor elsewhere in the Enneads as well. ${ }^{47}$ He affirms that there is apprehension when thought rolls back, and the activity according to the life of the "higher" soul is projected back, just as images are reflected on a bright, shiny mirror. According to Plotinus, when the mirror is tarnished or not in the right state, the image would be still there but its vision would be severely affected. ${ }^{48}$ In an analogous manner, when the faculty of the imagination in us which reflects the images of reasoning and thought is undisturbed, it sees and knows them as it happens in the case of sense-perception $1 .{ }^{49}$ As for the role of imagination in apprehending the sensibles, he states:

For remembering is either thinking or imaging; and the image comes to the soul not by possession, but as it sees, so it is disposed; and if it sees sense-objects, it sinks low in proportion to the amount of them it sees. For because it possesses all things in a secondary way, and not so perfectly [as intellect $]. .{ }^{50}(145)$.

So, an object of sensation (aisthema) is also equally represented or reflected in the imagination. The soul thus remembers and intellects both the sensible and the intelligible by recourse to imagination which is situated in the middle the two. For Plotinus, the imagination

\footnotetext{
${ }^{46}$ For the literature on the "imagination" in Plotinus, see, inter alia, John Dillon, "Plotinus and the Transcendental Imagination," in James Mackey (ed.), Religious Imagination (Edinburgh: Edinburgh University Press, 1986); G. M. Hutchinson, "Apprehension of thought in Ennead 4.3.30," The International Journal of the Platonic Tradition 5 (2011): 262-82; Anne Sheppard, "the Mirror of Imagination: the Influence of Timaeus 70eff," Ancient Approaches to Plato's Timaeus, University of London: Bulletin of the Institute of Classical Studies Supplement 78, (2003): 203-212; Edward Warren, "Imagination in Plotinus," The Classical Quarterly 16, no. 2 (1966): 277-285. It is to be noted that this study has not treated the issue of "higher" versus "lower" imagination in Plotinus, since this is beyond the scope of present research.

${ }^{47}$ Plotinus, Enneads 1.4.10.21ff. Cf. Hutchinson, Apprehension of thought in Ennead.

${ }^{48}$ Hutchinson, Apprehension of thought in Ennead 4.3.30, 276.

${ }^{49}$ Plotinus, Enneads 1.4.10.6-16.

${ }^{50}$ Ibid., 4.4.3.8-12.
} 
plays a crucial role in the apprehension of both the sensibles and the intelligibles. He holds that the imagination is responsible for presenting activities that occur in parts of the soul to the attention of the whole soul.

\section{Galen: Earliest Traces of the Internal Senses?}

Galen was born in Pergamum in Greek-speaking Asia Minor in 129 CE, but spent most of his mature years (after 161 AD) in Rome, where he probably died, sometime after $200 .^{51}$ His corpus is wide-ranging comprising treatises on logic, anatomy, physiology, theory of the fundamental elements, disease classification, techniques of diagnosis and prognosis, therapeutics, ethics and finally, philosophical psychology. Galen also had a philosophical training, and his works shows a serious engagement with philosophy, which was for him both an additional accomplishment, to be taken seriously as his medical work, and something informing his scientific thought.

Galen does not present philosophical proofs for the existence of the soul; rather he takes it to be self-evident, and accepts that humans are a composite of body and soul. ${ }^{\mathbf{5 2}}$ For Galen the rational soul is responsible for sensation and voluntary motion, and resides somewhere in the brain substance. ${ }^{53}$ In his psychology, the activities (which he equates with dunameis) of the soul include the functions of imagination, reason and memory. However, it is important to note that these too are not located in any specific part of the brain. Galen states in his On the Doctrines of Hippocrates and Plato that the head houses "imagination and memory and recollection, knowledge and thought and ratiocination, and in its relation to the other parts of the animal to guide the sensation of the sensory parts and the motion of the parts that move voluntarily". ${ }^{54}$ As for the heart, however he claims that its function is "to provide the 'tone' of the soul," and to

\footnotetext{
${ }^{51}$ For a brief and concise view on Galen's life and works see P. N. Singer, Galen: Psychological Writings (Cambridge: Cambridge University Press, 2013), $1 \mathrm{ff}$.

52 For more information on this, see Pierluigi Donini, "Psychology" in R. J. Hankinson (ed.), The Cambridge Companion to Galen (Cambridge: Cambridge University Press 2008), 184-209, esp. 184.

${ }^{53}$ See Christopher D. Green, "Where did the Ventricular Localization of Mental Faculties Come from?," Journal of History of the Behavioral Sciences 39, no.2 (2003): 131-142; and Peter E. Pormann, "Avicenna on Medical Practice, Epistemology, and the Physiology of the Inner Senses," in Interpreting Avicenna, ed. Peter Adamson (Cambridge: Cambridge University Press, 2013), 91-108.

${ }^{54}$ Galen, On the doctrines of Hippocrates and Plato (PHP), trans. P. de Lacy, (Berlin: Akademie-Verlag 1980), vol. 1, 440.
} 
provide the boiling, as it were ..." in states of passion. ${ }^{55}$ Finally, the liver is thought to be the house of the faculty of nutrition and the "enjoyment of pleasures." 56 Thus, it is difficult to see a "ventricular" localization of the faculties in Galen's physiology. However, what is noteworthy in Galen's psychology is not its all-encompassing scope but rather its plasticity that provided the space for speculative interpretation. Thus later thinkers - medical, philosophical or theologicalmodified Galen's distinction between the physiology of the ventricles and the activities of the rational soul, laying the groundwork for the placement of the imagination, reason, and memory within a separate ventricle, as we have seen in the case of Nemesius for example. ${ }^{57}$ Although the concept of a formal ventricular localization is a significant feature of the developing dogma of Galenism, it is difficult to verify exactly when and by whom this localization came about. ${ }^{58}$ According to Aëtius of Amida (ca. 530-560 AD), the physician Posidonius of Byzantium (fl. end of the fourth century AD) apparently placed the imagination in the forepart of the brain, reason in the middle cavity and memory in the hind part of the brain. ${ }^{59}$ It is significant that Posidonius was a contemporary of Nemesius in whom a more explicit "localization" theory is to be found, as observed in section II. However, Nemesius' localization theory was somewhat different from that of Posidonius. ${ }^{60}$

In what follows, Galen seems to suggest that perception takes place through some faculty which is "common" to all the senses, i.e. the external senses. Although he does not name it as "common sense," it is very likely that he has in mind something of this kind. Citing the authority of Plato, he asserts that the external senses are the instruments of the body, and each sense-organ responsible for a particular sense-perception, viz., sight, hearing etc. cannot function in lieu of one another. That is to say, the sense-objects of hearing cannot be perceived through sight, and vice-versa. Still quoting Plato, Galen argues that if there is no common faculty that can perceive

\footnotetext{
${ }^{55}$ Ibid., 440-41.

${ }^{56}$ See also Green, Where did the Ventricular, 136.

${ }^{57}$ Julius Rocca, Galen on the Brain. Anatomical Knowledge and Physiological Speculation in the Second Century AD, (Leiden: Brill, 2003), 245ff.

${ }^{58}$ It has been suggested that Porphyry (232/3-c. 305 AD) invented the first theory of localization, see Rocca, Galen on the Brain, 246.

${ }^{59}$ Ibid., 245-246.

${ }^{60}$ J. Scarborough, "Symposium on Byzantine Medicine. Introduction", Dumbarton Oaks Papers 38 (1984): ix-xvi.
} 
different sense-data, e.g. speech and color simultaneously, then we would not be able to have any thoughts about them that are "common" to these data. As he states:

For that which first perceives, whatever it may be, is common to all the senses, as Plato teaches in other places and especially in the Theaetetus, in the part of the work where he says, "it would surely be strange, my young friend, if some large number of senses were seated in us as in wooden horses and if all these things did not reach to some one form, whether soul or whatever one should call it, by which we perceive, through the senses as instruments, all things that are perceptible."... "These instruments through which you perceive things that are hot and hard and light and sweet, do you not say that each of them belongs to the body, or do you say that they belong to something else?-To nothing else. Would you also be willing to agree that the things you perceive through one faculty cannot be perceived through another, that the objects of hearing, for example, cannot be perceived through sight, or the objects of sight through hearing? ... If, then, you have any thoughts about both sets of objects, your perception about both would not be made through the one sense organ, nor yet through another?... Consider speech and color: is not your first thought about them precisely this, that both exist?... And that each of the two is different from the other, but the same as itself?.... And that both taken together are two, but each by itself is one?... And are you able to observe whether they are unlike or like each other?... By what means do you have all these thoughts about them? For it is not possible to get either through sight or through hearing what is common to both. And here is still further evidence of the point we are making. If it were possible to ask whether both are salty or not, you know that you could tell me what instrument you would use in the inquiry, and this is obviously not sight or hearing, but some other.-Of course, it will be another, the faculty that works through the tongue.-Very true. But through what does the faculty work that tells you what is common not only to these objects of sense but to all, to which you apply the term 'is' and 'is not,' and the other terms that we used just now in our questions about them? For all of these, what kind of instruments will you name, through which the perceiving part of us perceives each one of them?",61

Continuing the argument, he suggests that there is a "common faculty" (other than the five senses) that reaches from the brain through the nerves to each of the sense organs, and makes perception possible. He also describes the physiology of how this common faculty changes concurrently with the qualities specific to a particular organ of sense. In his own words:

Here, as in the passages that follow and in other dialogues, Plato taught us about the common faculty which reaches from the brain through the nerves to each of the sense organs and perceives the qualities in them, the implication being that if it had not been possible for any but the luminous organ to change concurrently with the qualities peculiar to light, or any but the vaporous organ to change concurrently with the qualities peculiar to vapors, ... or any but the organ that tastes and is full of juices with the qualities peculiar to moist bodies, the sense organs would not have come into being. But as things are, this is not the case. ${ }^{62}$

A large portion of On the Doctrines of Hippocrates and Plato is devoted to refuting the Stoic view that "heart" is the seat of the principal part of the soul, i.e. the ruling part

\footnotetext{
${ }^{61}$ Galen, PHP, VII 6.4-27, trans. De Lacy.

${ }^{62}$ Ibid., 22-27
} 
(hegemonikon). ${ }^{63}$ Galen writes that the Stoics concede that the ruling part is the source of sensation and volition. Therefore, if they are to demonstrate that the heart contains within itself the ruling part, it should begin with the premise that it is this that initiates every voluntary movement in every other part of the animal, and that each sensation is referred to it. He then goes on to challenge the empirical basis of this claim. To show that the Stoic claim is contrary to evidence, Galen refers to the anatomical experiments which can prove with absolute certainty that the vessels which originate in the heart have no connection with the transmission of voluntary movement and sensation, which are rather to be assigned to nerves originated in the brain. Galen, then, summarizes his arguments as follows. He claims that both doctors and philosophers agree that "where the source of the nerves is, there too is the ruling part of the soul." Now scientific experiments have shown decidedly that "the origin of the nerves is in the brain" in contrast to the Stoic claim that "the origin of the nerves is in the heart." Therefore, the conclusion becomes easy to follow, i.e., the ruling part resides in the brain. As Galen writes:

No Stoic or Peripatetic philosopher and no physician is as bold as before, and some, at least, have publicly changed over to the true account, the physicians admitting that the faculty of sensation and motion flows from the brain to all the animal's members, and the philosophers that the reasoning part of the soul is situated there. For they were put to shame when one of their two premises was clearly refuted by dissection, the one that vitiated their reasoning when they used it as their leading premise, adding to it the premise granted by all, that 'Where the nerves have their source, there the governing part is'... They thought "nerves come from the heart"

Galen assigns different faculties (dunameis) to the rational soul, which he locates in the brain, as noted earlier. In his view, these faculties are sense-perception, imagination, memory, and deliberate movement. He notes that some of these faculties are also shared by other animals. Here, he outlines a theory of action, involving the role of imagination and assent within the rational soul, which seems to apply also to animals. ${ }^{65}$ It is interesting to note that Galen acknowledges that there is the intellect besides the rational soul, and also, his analogy of the intellect's relation to the soul is revealing. According to Galen, the sensory faculty, by which he might have in mind "the common sense," is that which notices all sorts of sensory changes in the body. Taking into account what he has said in the passage quoted from the PHP, it most likely

\footnotetext{
${ }^{63}$ Galen, $P H P$, esp. book III and IV.

${ }^{64}$ Galen, PHP VII.1, 1-6.

${ }^{65}$ Galen, Character Traits 45 Kr., 164, trans. in P. N. Singer (ed.), Galen: Psychological Writings (op. cit.).
} 
refers to his notion of "the common sense." As for "memory," he rather defines it in an Aristotelian way, i.e., the faculty that retains the residue of sensory experience and is able to recall it subsequently:

The rational soul is that to which the intellect stands in the same relationship as the eye to the body; it also has other capacities (dunameis) besides the intellect whose actions are evident: the capacity of sense perception, the capacity of imagination, the capacity of retention (memory), and the capacity by which deliberate movement comes about. The sensory capacity is that which notices the changes that occur in each one of the members of the body; then another capacity, whose function is that of retention (memory) and subsequent recall retains what the sensory capacity has noticed. Then thinking and scrutiny investigate many of the things that are pictured in the imagination when we want to scrutinize something to do with the arrangement of our well-being or our social intercourse or something to so with the sciences and or the arts. Then thought and scrutiny are followed by a decision upon one of the things investigated and examined by thought from among those which occur in the imagination. ${ }^{66}$

Finally, Galen explains the imagination in the following manner:

What I mean by 'imagination' is every movement that comes about in the soul of the sort that happens in it when a change occurs in the body. We sometimes incline towards this movement and decide to approve and accomplish it, and we sometimes refrain from that. If we incline towards it and decide upon it, and it is something that can be done, a longing to accomplish it is stirred up in us; if we do not incline towards it and do not decide upon it, but reject it and refrain from it, a revulsion from it is stirred up in us. If we neither decide upon it nor reject it, but either continue to scrutinize it or despair of attaining knowledge of it and abstain from it, we are affected by hesitation and uncertainty. ${ }^{67}$

It is notable that Galen describes the imagination in the above in terms of various movements that occurs in the soul. It is possible that he has in mind "imaginary" thoughts when discussing imagination rather than an image whose source may be some external sensation. In The Capacities of the Soul, Galen reiterates the rational soul's different faculties. ${ }^{68}$ At first, he clarifies the very notion of "dunamis," noting that as long as we are ignorant of the substance of the active cause, we call it dunamis. ${ }^{69}$ In his view, faculties are to be understood in the sense of a substance having different activities, e.g., aloe has a faculty/capacity of cleansing and toning mouth of the stomach. ${ }^{70}$ In likewise manner, he suggests that the soul has different faculties, each responsible for a particular task. It is to be noted that the list of dunameis thus specified within

${ }^{66}$ Galen, Character Traits, 45 Kr., 164.

${ }^{67}$ Ibid., 165

${ }^{68}$ Galen, The Capacities of the Soul Depend on the Mixtures of the Body (QAM) 770 K., 377, trans. in Galen: Psychological Writings, op. cit.

${ }^{69}$ Galen, QAM, 34 M., 376-77. Note also that "dunamis" is translated as capacity in Singer, Galen: Psychological Writings.

${ }^{70}$ Ibid., 377. 
the soul appears differently at different places, e.g., in the PHP the list includes phantasia, anamnesis, mneme, episteme, noesis, and dianoesis. ${ }^{71}$ However, in the present context he mentions perception, memory, and understanding ${ }^{72}$ :

And in the same way, when we say: 'the rational soul, seated in the brain, is capable of perceiving through the organs of perception, is capable of remembering the objects of perception of on its own, of seeing consequence and conflict in things, and their analysis and synthesis, we are not indicating anything different from what we would if we were to make the summary statement: 'the rational soul has a number of capacities (dunameis): perception, memory, understanding, and each of the others. ${ }^{73}$

\section{Summary and Conclusion}

This study has attempted to trace the notion of the internal senses in three ancient authors. It started with Nemesius, and then by going backward ends with Galen. The textual evidence investigated in this study shows clearly that Galen, after acknowledging the Platonic tripartite soul, locates the various dunameis of the soul in the brain. ${ }^{74}$ However, it is to be noted that he merely locates them in the substance of the brain, without being explicit as to whether they can be located in the "ventricles" of the brain. This conclusion is in line with the findings of Christopher Green, cited earlier in the article. ${ }^{75}$ According to Green, a full-fledged ventricular theory is to be found in Nemesius. Before Nemesius, Galen contended that the mental faculties were located in the substance of the brain rather than in the ventricles. But it was only with Galenism, i.e. later philosophers who, using Galen's anatomy as a point of departure, located the mental faculties in the ventricles themselves. The ventricular localization theory, in Green's

\footnotetext{
${ }^{71}$ Galen, PHP, 438,27-440,8 De Lacy trans. See also Singer, Galen: Psychological Writings, 377.

72 On "understanding" Galen states in De moribus (which survives only in the Arabic) that: "Understanding resides only in the rational soul, and is a faculty that perceives agreement and disagreement in all things." XXXVIII, 212; cited in J. N. Mattock, "A Translation of the Arabic Epitome of Galen's Book Peri êthôn," in Stern, Hourani and Brown (eds.), Islamic Philosophy and the Classical Tradition: Essays Presented by his Friends and Pupils to Richard Walzer on his Seventieth Birthday (Columbia: University of South Carolina Press, 1972), 235-260

${ }^{73}$ Galen, QAM, 33 M., 377.

${ }^{74}$ See among others, Jacques Jouanna, Does Galen have a medical programme for intellectuals and the faculties of the intellect? in Christopher Gill et al. (eds.), Galen and the World of Knowledge (Cambridge: Cambridge University Press, 2009), 190-205, at 193.

${ }^{75}$ See $n n 54$ and 57. It should however be noted that unlike Green's study, the central objective of this paper is not the localization of the mental faculties.
} 
opinion, came together piece by piece over a period of time, probably not appearing fully in the form known to the Medieval world until the Middle Ages themselves. All in all, although the exact origin of the ventricular theory cannot be ascertained, the framework for the theory was established in the anatomical doctrines of Galen, which then gained its functional aspects gradually in the works of figures such as Posidonius, Nemesius, and Augustine.

Be that as it may, it seems intuitive enough, that the localization theory of Galen played a crucial role in paving the way for the foundation of the internal senses, which both Plotinus and Nemesius adapted. Just as with the external senses one can locate various sense-organs in different parts of the body, viz., touch, smell, sight etc., so too with the internal senses, thanks to Galen, one is able to locate them in various organs of the body. Thus philosophers are able to explain the role of all these different (internal) senses in their account of perception. However, it is important to note that none of the authors, studied in this paper, have really accounted for the epistemic justification of the internal senses that one finds much later, e.g. in Avicenna. Galen, although touches upon the philosophical aspect of things at times, was more concerned with the physiology of the internal senses rather than with their epistemological underpinnings. Moreover, Galen, unlike Plotinus, lacks a full-fledged theory of the soul, which would otherwise be able to explain all the different functions of the soul within a coherent system.

Coming now to Plotinus, it is undeniable that he benefitted much from Galen's anatomical findings about the soul, which also helped him refute the Stoic doctrine of the soul, with its ruling part in the heart. ${ }^{76}$ However, it is clear that the difference between the Galenic and the Plotinian conceptions of the internal senses is, nonetheless, great. Although it might be the case that the Galenic localization of the internal senses had prompted Plotinus to distinguish each internal sense, it is important to note that for the latter, the "activities" of the soul are present in the brain, not the soul itself. But Plotinus makes use of Galen's findings about nerves to establish the claim that the ruling part of the soul is in the brain, and that the soul must require a ruling part in order to generate perception and meaningful understanding. Also, the notion of the ruling part stems from the idea that the soul is like a craftsman and parts of the body are its instruments. ${ }^{77}$ That being said, Plotinus does not seem to expand on the common sense, as does

\footnotetext{
${ }^{76}$ Blumenthal, Plotinus' Psychology, $75 \mathrm{ff}$.

${ }^{77}$ See Galen, On the Usefulness of the Parts of the Body 1.2, tans. M. T. May.
} 
Galen. Also, Galen's conception of memory and imagination does not deal the "aporiae" concerning them, as one finds them in Plotinus.

As for Nemesius, he is to be credited for explicitly assigning a place for each internal sense. That is to say, he located them in the ventricles of the brain. Like Plotinus, he too recognizes the role of memory and imagination in perception. Also, similar to Galen, he states that memory preserves the residue of external sensation. But there was no detailed account of all the problems that Plotinus identified with memory or the imagination as they relate to sense-perception. ${ }^{78}$ However, Nemesius does explicitly state that the soul has faculties, and these are thought, memory and the imagination. In this way, he contributed further to the development of the theory of the internal senses as it took shape in later centuries.

Muhammad U. Faruque University of California, Berkeley

\section{References}

Aëitius, A. 1935-1950. Libri medicinales. In A. Oliveiri (Ed.). Corpus medicorum Graecorum: Vol. 8. Berlin: Academiae Litterarum (original work written in the early sixth century).

Aristotle. 1984. The Complete Works of Aristotle: The Revised Oxford Translation. Edited by Jonathan Barnes. Princeton, NJ: Princeton University Press.

Armstrong, A.H. 1966-1988. Plotinus (The Enneads). Loeb Classical Library. 7 volumes. Cambridge, MA: Harvard University Press.

Avicenna. 1959. al-Shifä': fì al-nafs Fazlur. Fazlur Rahman (ed.), Avicenna's De anima (Arabic text). Being the Psychological Part of Kitāb al-Shifä'. London: Oxford University Press.

Black, D.L. 2000. "Imagination and Estimation: Arabic Paradigms and Western Transformations," Topoi, 19 (2000) 59-75.

Black, D.L. 1993. "Estimation (wahm) in Avicenna: The Logical and Psychological Dimensions." Dialogue 32: 219-258.

Blumenthal, H.J. 1971. Plotinus' Psychology: His Doctrines of the Embodied Soul. Martinus Nihjoff: the Hague.

Blumenthal, H.J. 1976. "Plotinus' Adaptation of Aristotle's Psychology: Sensation, Imagination, and Memory". the Significance of Neoplatonism. Ed. R. Baine Harris. International Society for Neoplatonic

\footnotetext{
${ }^{78}$ See the section on Nemesius.
} 
Studies. Norfolk, VA: Old Dominion University, 41-58 (reprinted in Blumenthal, H.J. 1993. Soul and Intellect: Studies in Plotinus and Later Neoplatonism Aldershot, Hampshire: Variorum).

Brisson, L. and Pradeau, J.F. 2002-2010. Plotin Traités. 9 volumes. Paris: GF Flammarion.

Caluori, Damian. 2005. “The Essential Functions of a Plotinian Soul”. Rhizai Vol. II, No. 1, 75-93.

Dillon, John. 1986. "Plotinus and the Transcendental Imagination". Religious Imagination. Ed. James Mackey. Edinburgh: Edinburgh University Press.

Donini, Pierluigi. 2008. "Psychology." In R. J. Hankinson (ed.), The Cambridge Companion to Galen. Cambridge: Cambridge University Press.

Emilsson, Eyjolfur K. 1988. Plotinus on Sense-Perception: A Philosophical Study. Cambridge:

Cambridge University Press.

Galen. 1916. Galen on the Natural Faculties (A. J. Brock, trans.). Cambridge, MA: Harvard University Press.

Galen. 1968. Galen on the Usefulness of the Parts of the Body (M. Tallmadge May, trans.). Ithaca, NY: Cornell University Press.

Galen. 1976. Galen on the Affected Parts (R. E. Siegel, ed. and trans.). Basel, Switzerland: S. Karger.

Galen. 1980. On the Doctrines of Hippocrates and Plato (3 vols., P. de Lacy, trans.). Berlin: AkademieVerlag.

Galen. 1997. Galen: Selected Works. P. N. Singer (ed. and trans.). Oxford, New York: Oxford University Press.

Green, Christopher D. 2003. "Where did the Ventricular Localization of Mental Faculties Come from?" Journal of History of the Behavioral Sciences 39, no.2 (2003): 131-142.

Guyer, Paul. 1987. Kant and the Claims of Knowledge. Cambridge and NY: Cambridge University Press.

Hankinson, R.J. (ed.). 2008. The Cambridge Companion to Galen. Cambridge: Cambridge University Press.

Hasse, D.N. 2001. “Avicenna on Abstraction.” In R. Wisnovsky (ed.). Aspects of Avicenna. Princeton: Markus Wiener Publishers.

Johansen, Thomas K. 2005. In Defense of Inner Sense: Aristotle on Perceiving that One Sees, Proceedings of the Boston Area Colloquium in Ancient Philosophy 7 (2005): 235.

Jouanna, Jacques. 2009. Does Galen have a Medical Programme for Intellectuals and the Faculties of the Intellect?" In Christopher Gill et al. (eds.), Galen and the World of Knowledge. Cambridge: Cambridge University Press.

Kant, Immanuel. (1781/1787). Critique of Pure Reason, P. Guyer and A. Wood (trans.), Cambridge and NY: Cambridge University Press, 1997.

King, R.A.H. 2009. Aristotle and Plotinus on Memory. Berlin and New York.

Lagerlund, Henrik (ed.). 2007. Forming the Mind: Essays on the Internal Senses and the Mind/Body Problem from Avicenna to the Medical Enlightenment. Studies in the History of the Philosophy of Mind, 5. Dordrecht: Springer.

Mattock, J.N. 1972. "A Translation of the Arabic Epitome of Galen's Book Peri êthôn.” In Stern, Hourani and Brown (eds.), Islamic Philosophy and the Classical Tradition: Essays Presented by his Friends and Pupils to Richard Walzer on his Seventieth Birthday (Columbia: University of South Carolina Press. 
Nemesius, On the Nature of Man, trans. R. W. Sharples and P. J. van der Eijk (Liverpool: Liverpool University Press.

Pormann, Peter E. 2013. "Avicenna on Medical Practice, Epistemology, and the Physiology of the Inner Senses." In Interpreting Avicenna, ed. Peter Adamson. Cambridge: Cambridge University Press.

Rocca, Julius. 2012. "From Doubt to Certainty. Aspects of the Conceptualisation and Interpretation of Galen's Natural Pneuma." In M. Horstmanshoff, H. King, C. Zittel (eds), Blood, Sweat and Tears. The Changing Concepts of Physiology from Antiquity into Early Modern Europe. Leiden: Brill.

Scarborough, J. 1984. "Symposium on Byzantine Medicine. Introduction”, Dumbarton Oaks Papers 38 (1984): ix-Xvi.

Sheppard, Anne. 2003. "The Mirror of Imagination: the Influence of Timaeus 70eff ". Ancient Approaches to Plato's Timaeus. University of London: Bulletin of the Institute of Classical Studies Supplement 78, 203-212.

Singer, P.N. 2013. Galen: Psychological Writings. Cambridge: Cambridge University Press.

Tieleman, Teun. 1998. "Plotinus on the seat of the soul: reverberations of Galen and Alexander in Enn. IV, 3 [27], 23," Phronesis 43 (4), 306-325.

Warren, Edward. 1966. "Imagination in Plotinus," The Classical Quarterly 16, no. 2 (1966): 277-285.

Warren, E.W. 1965. "Memory in Plotinus," CQ 15: 252-260.

Wolfson, H.A. (1935). The Internal Senses in Latin, Arabic, and Hebrew Philosophic Texts. Harvard Theological Review, 28, 69-133. 